\title{
Towards participatory environmental management?
}

\author{
Ilan Kapoor \\ Faculty of Environmental Studies, York University, 4700 Keele Street, Toronto, Ontario, Canada \\ M3J 1P3
}

\begin{abstract}
While the mainstream approach to environmental management (EM) has tended to be centralized, adopting a narrow conception of 'environment', there is a growing body of literature supporting a participatory approach which is decentralized, community oriented and holistic in its view of the environment. This paper examines the main principles underlying this development and assesses the opportunities and constraints associated with it. It concludes that, while participation is conducive to a localized and inclusive approach to EM, many questions remain about the extent to which it is meaningful in practice or can be institutionalized.
\end{abstract}

(C) 2001 Academic Press

Keywords: environmental management, community-based resource management, participatory development.

\section{Introduction}

The mainstream approach to environmental management (EM) has tended to be centralized and exclusionary and to take a narrow view of what constitutes the 'environment'. It has been implemented by hierarchically-organized bureaucracies that often exclude public input and participation, and has often been supported by an orthodox scientific paradigm that neglects the long-term environmental and social consequences of the unfettered exploitation of nature. However, there is an emerging body of literature supporting a participatory approach which is decentralized, community oriented and holistic in its view of the environment. Participation here is aimed at making environmental decisionmaking socially inclusive and environmentally sustainable.

Email: ikapoor@yorku.ca

This paper is a revised and expanded version of a paper bearing the same title and written for the United Nations Office for Project Services (UNOPS), Rome in May 2000.
This paper will attempt to take stock of, and critically reflect upon, the current directions of participatory EM. Its main argument is that while participation is conducive to a localized and inclusive approach, many questions remain about the extent to which it is meaningful in practice or can be institutionalized. How inclusive is it? What institutional arrangements exist, or are required, for participation? What power relations (e.g. between local/national/global actors, or government/private sector/community actors) and gender relations are implied by greater public involvement? What is meant by 'community'? What ingredients other than community involvement (e.g. property arrangements) are needed for participation to be consequential? The paper will address these questions, drawing on examples where appropriate. In so doing, it will highlight both the opportunities and limits of participatory EM.

After briefly outlining the principal characteristics and consequences of mainstream EM, the reasons for the emergence of the participatory approach will be identified. Next, the main features and benefits of this emerging approach will be highlighted both in theory and, with the help of two 
examples (see Appendix), in practice. The paper concludes with a discussion of the implications and constraints of the emerging participatory approach.

\section{The mainstream approach to EM}

Developed mainly in western, capitalist countries, but dominant now in most of the world, the mainstream approach to EM is premised primarily on an orthodox scientific paradigm (Shiva, 1986; Uphoff, 1992; Sachs, 1993; Dyck, 1998), which upholds a universal, objective reality that can be broken down into component parts by an 'impartial' and 'rational' observer, and then analyzed and acted upon. Nature, in this view of things, is separated from human experience so that human beings are able to exploit it without limit and consequence. It is seen as inert and passive: humans can 'manage' it, use it as a 'resource' or degrade it without fearing the after-effects.

The rationality of this approach is reflected in the organization of activities established to manage nature. In the hands of governments and bureaucracies, whose role by and large is and has been to regulate the natural environment, rationalism has evolved a top-down managerial approach. In principle, this means that decisions taken at the top are implemented by the lower ranks through the most 'efficient' means possible (Weber, 1946). EM has been organized, as a result, in a centralized and hierarchical way (Sachs, 1993; Quarles et al., 1988; Chambers, 1989). Relying on the idea of 'nature as resource', its primary purpose in developed or developing countries has been to service unfettered economic growth (Redclift, 1984, 1987). Mainstream environmental managers and scientists have, accordingly, devised 'efficient' technological means to realize such growth. This has usually involved a bias towards capital-intensive, and hence energy and resource-intensive, industrialization.

All this has had at least two important socioeconomic and political consequences, particularly in the developing world. The narrow conception of environmental policy, defined in relation only to the 'natural' environment and exclusive of the 'social' environment, has put many people's lives at risk. The socio-economic activities of large sections of the inhabitants of developing countries are closely bound up with their natural surroundings, many of them deriving their livelihoods from direct access to land, water and forests. Environmental exploitation and degradation, in the form of deforestation or the construction of dams, mines and roads, has therefore meant the endangerment of these people's lives (Gadgil and Guha, 1993). In addition, priority given to economic growth has often led to state annexation and privatization of resources (e.g. the conversion of state forest land to private agricultural land), thereby further reducing or restricting people's access to their immediate environments (Guha, 1989). Increasingly, such privatization has been directed at attracting multinational agro-industrial investment (Stanford, 1994; Amalric, 1998) to encourage cash crop exports and attract modern agricultural technologies (e.g. biotechnology).

Women and indigenous peoples have been particularly hard hit by this process (Braidotti, 1994; Agarwal, 1997). Women must work doubly hard in fields degraded by soil erosion and walk longer distances to fetch water or firewood when water tables run low or forests are destroyed. Working days get longer and childcare suffers. Similarly, indigenous/aboriginal peoples throughout the globe have seen their lives, if not their worlds, destroyed by state appropriation of their ancestral lands (Viegas and Menon, 1989; Brush and Stabinsky, 1996). Nature and land feature centrally, not only in their socio-economic survival, but in their cultural and religious worldviews as well.

The second consequence has been that people have tended to be seen as obstructing 'rational' and 'scientific' management of resources. Environmental policy-makers have used the neo-Malthusian argument that it is exploding population growth in the developing world that is the main cause of environmental destruction and that poor people (i.e. rural and indigenous people, forest-dwellers) exploit resources selfishly and without restraint ${ }^{1}$ (Meffe et al., 1993). State paternalism towards these people is therefore seen as justified, with government environmental managers disparaging 'traditional' peasant ecological knowledge in favour of teaching them 'modern' conservation practices.

Thus, one of the enduring features of latter-day EM has been its de-politicization (or at least its constricted politics). The treatment of nature as 'resource', the centralized and hierarchical bureaucratic organization of EM, the priority of growth, have all tended to reinforce the environmental manager's view of 'nature' as separate from

\footnotetext{
${ }^{1}$ Several analyses show that the private sector, often with the state's blessing, has in fact been the main culprit. As a result, environmental managers have it backwards: it is not that people are poor and consequently degrade their environment, but rather that people are poor because the environment on which they rely has been degraded. See Guha and MartinezAlier (1997, Ch. 3).
} 
'society'. The high degree of state power over the environment has translated into the absence or removal of avenues for input and contestation by people. EM has proceeded with a narrow set of perceptions and interests, exclusive of social (or indeed 'ecological') ones. It is this narrow politics that participatory EM attempts to redress.

\section{Towards participatory EM}

Criticism of mainstream EM began in the 1960s and 1970 s and gained increasing momentum in the following decades. There has been increasing awareness of environmental problems, both locally (problems of deforestation, soil erosion and depletion, air and water pollution, fisheries depletion, etc.) and globally (problems of global warning and climate change, ozone depletion, acid rain, etc.). A sizable section of the general public and the scientific community has begun to seriously question the wisdom of unlimited socio-economic growth and the orthodox scientific idea of humans being able to insulate themselves from environmental degradation. This questioning has been supported by the emergence of the sustainability paradigm in development, which upholds environmentally sustainable growth.

Concomitantly, there has been ongoing popular resistance around the world - examples include the Indian Chipko/forestry movement, the Kenyan Green Belt Movement, as well as green parties in Western Europe - to environmentally-hazardous development and top-down EM (Guha, 1989; Taylor, 1995). At least two factors have strengthened this resistance, particularly in the developing world: (1) the inability of states to police people and prevent them from accessing the environmental resources required for their survival; and (2) the notable failure of state-run conservation projects, many of which have been unable to provide adequate incentives for people to 'buy into' such projects (Wells and Brandon, 1992).

Countering the view that local communities cannot engage in 'rational' ecological practices, several studies have upheld community-based conservation, showing numerous community practices and 'traditional' farming techniques to be historically sustainable (Perry and Dixon, 1986; Shiva, 1991; Vivian, 1991; Bromley, 1992; Alcorn, 1993; Raju, 1993). For example, shifting cultivation, a practice involving the clearing/burning and cultivation of patches of forest in rotation, has been frequently banned by colonial and post-colonial administrators in developing countries. Yet, because the practice allows the plots left fallow to recover their lost nutrients and vegetation, it has been shown to enhance biodiversity (Gadgil and Guha, 1992: 150ff; 219ff.; Leach and Mearns, 1996:12ff.). Similarly, traditional community forestry entails communal labour to plant and maintain trees, giving community members access to forest resources as regulated by a system of socio-religious rules. Not only has this practice been shown to be a sophisticated management system, it has often proven to be a more successful system for reforestation than state or private sector-run reforestation schemes (Guha, 1989: 180).

In the face of this mounting evidence, the 1992 UN Conference on Environment and Development (UNCED) agreed under Agenda 21 to emphasize the importance of rethinking the 'blueprint' approach to EM in favour of one that involves people's participation and accommodates indigenous knowledge and local values and interests (United Nations, 1992). Since then, many governments, communities, non-governmental organizations (NGOs) and international development agencies have adopted this approach (O'Riordan and Voisey, 1997, 1998).

Participatory EM was initially inspired by the work of critical theorists such as Paulo Freire (1970). In the 1980s, it was given impetus by NGO-developed participatory approaches to the delivery and evaluation of programmes (Chambers, 1994a-c; Craig and Mayo, 1995). It frequently involves interdisciplinary research by social scientists and scientists. Whereas the orthodox scientific approach saw reality as universal and objective, the new approach sees it as socially constructed and culturally specific. 'Truth', 'fact' and 'cause-effect' are not revealed through the single lens of the outside 'expert', but constructed inter-subjectively through the multiple perspectives of all relevant programme participants or 'stakeholders'. Rather than outside programme managers and policymakers unilaterally defining environmental programmes, stakeholders are empowered, through a process of group learning and consensus-building, to create and manage their own programmes. Local communities are encouraged to develop this participatory process on their own, or if required, with the help of outsiders (government, international agency or NGO staff) who act as catalysts or facilitators of the process (Chambers, 1994a-c; Holland and Blackburn, 1998).

The participatory approach to EM does not exclude such concerns as programme efficiency and effectiveness or environmental impact, which have tended to be the focus of the mainstream 
approach. What is new is that these are made secondary to other concerns. The process through which knowledge is acquired and decisions are taken is accentuated, so that questions of efficiency, effectiveness and impact 'for whom?' and 'as determined by whom?' are prioritized. Group learning and empowerment engender the transformation of these terms, infusing them not just with mainstream economic and scientific/technological concerns but also with socio-ecological ones, such as ensuring income generation for community members or assessing impact of programmes on nature, wildlife and women. This politicization and democratization of the EM process helps move it away from an expert culture to more of a lay one, grounded in community life and concerns.

The following are some of its main features and benefits, in theory at least:

(1) Participation expands the programme information and representation base. Convening all relevant community stakeholders can help:

(a) ensure the representation of a diversity of community/social groups, especially traditionally marginalized groups such as women, aboriginal people, migrants or cultural minorities. Programmes are thus tailored to the needs and interests of stakeholders, including not just community groups, but also NGOs, funding agencies (where relevant), local and central government officials, and private sector organizations, the idea being to construct as wide a consensus as possible. The participatory process aims at enhancing mutual understanding.

(b) build on the wide variety of information and knowledge held by the diversity of stakeholders. This is particularly important for environmental programmes as it helps coordinate information across ecosystems and across sectors (physical environment, infrastructure, health, education, housing, etc.). In turn, this ensures taking a holistic environmental approach and multi-dimensional programming (Perry and Dixon, 1986).

(c) incorporate local knowledge, experience and creativity, including ecological, cultural and socio-political practices and institutions.

(2) Participation helps clarify and stabilize communications and power relationships between stakeholders. Uncertainty and misinterpretation of programme contents, procedures and results are thus minimized, making communication among stakeholders more transparent.

(3) Participation enhances iterative programming. While iteration and feedback loops have been part of mainstream EM for many years, the idea here is to open up communication even more to allow for dynamic learning and for programme managers to build on experience and learn from mistakes. Programmes can, therefore, become more flexible, and activities and resources can be re-oriented mid-stream if needs be (Plein et al., 1998).

(4) Participation encourages local ownership, commitment and accountability. When stakeholders are excluded from programming decisions, they will tend to feel removed from responsibility for the results. Their inclusion, on the other hand, helps them 'buy into' the programme, and makes them feel empowered and accountable. Such ownership, in turn, spurs team-building, joint problem-solving and local management capacity (Zazueta, 1995).

The examples listed in the Appendix - one from a developing country (Nepal), the other from a developed country (Canada) - are two of many that could be cited to illustrate current practice. Both involve participation, yet each goes about it differently. A notable area of divergence concerns the institutionalization of participation. The Nepali programme involves broad-based community development, with people's participation channeled through existing community institutions (i.e. the panchayats). The Canadian programme is comparatively less broad (although still multi-dimensional), and it creates new mechanisms and consultative processes to foster community participation. The Nepali programme starts with, and builds on, an existing community, while the Canadian one makes concerted efforts to construct a community through a shared local environmental agenda (more on this later). A final difference concerns the rural versus urban focus of each example. The Nepali programme responds to the primarily rural nature of Nepali society, while the Canadian programme is emblematic of the trend towards urbanization that EM will increasingly need to cope with in the future in both developed and developing countries. Urbanization brings with it denser and more diverse concentrations of people and socio-economic activities; these, in turn, generate higher risks for environmental hazards, increased pressures on limited resources (environmental, institutional, human, socio-economic), and the 
greater need to respond to public needs and demands.

\section{Constraints and implications}

Many analysts (myself included) have welcomed this development because it aims at a holistic approach to EM, it is decentralized and community oriented, it puts people and equity (not just growth) first, and it pays particular attention to issues of inclusion/marginalization (of women, indigenous peoples and minorities). The attractiveness of the participatory approach in theory, however, does not necessarily translate into successful practice. Indeed, despite its relative success in some cases (as illustrated in the examples). there are a number of constraints and implications worth noting. The following is an analysis of some of the major concerns, recognizing that further thought, research, experimentation and experience are required.

\section{Institutional concerns}

That there is a trend within communities, governments and international development agencies towards adopting participatory approaches to EM does not imply that it is easily realized. Many commentators point out that while some groups and institutions have taken up these approaches, some have not and many are doing so only partially or in stages (Garcia-Zamor, 1985; Montgomery, 1988; Nelson and Wright, 1995; Zazueta, 1995; Shepherd, 1998; Blackburn, 1998). For instance, Participatory Rural Appraisal techniques may be used to evaluate an environmental programme, but no provisions for participation exist in other programming or management areas (i.e. at the design or implementation stages). Participation thereby becomes a simple 'add-on' to programming.

There are several reasons for this restraint and lack of integration. First, institutions may be holding back because participatory approaches entail, at least at the outset of programmes, a heavy commitment of time and resources (human, institutional and financial) to ensure adequate stakeholder involvement. More time and effort will be needed, therefore, to better institutionalize participatory approaches and to further develop tools and techniques for their application to EM. Secondly, there may be institutional reticence: to be meaningful, the transition towards participation requires nothing less than a change of organizational culture, involving a movement towards broader, more flexible and longer-term goals, procedures, results and time horizons. These behavioural changes, in turn, depend on much deeper structural and political changes such as political leadership and will, the establishment of appropriate legal frameworks, etc. Often, these changes are not happening, or if they are, they are severely compromised by corruption and other unaccountable political and administrative barriers. In some cases, government commitment to, and structures facilitating, participation and decentralization exist, but bureaucrats have little incentive (e.g. because of a loss of their discretionary power) to advertise or implement them (Berry et al., 1993: $42 \mathrm{ff.})^{2}$

Nonetheless, the transition from mainstream to participatory EM need not necessarily be government initiated. In fact, there is some evidence that it can be, and is, initiated by civil society organizations at the national and international level (Wapner, 1995; Blackburn, 1998). Many such organizations have established workable participatory environmental projects with local communities, and several have successfully pressured (through media campaigns, public demonstrations, etc.) reluctant governments or international agencies to at least begin making the necessary institutional changes. This pressure need not be confrontational; it is often more productive for NGOs and community groups to engage in constructive dialogue with government officials and funders so as to convince and educate them about the benefits of participatory programming.

But no matter who initiates participatory EM, for such a practice to be sustainable, it needs to be systematized. That is, participation needs to be integral not only to programming, but also to relationships among the different organizations involved in the programming. As the two examples in the Appendix illustrate, this usually means that local communities and organizations are supported by public policy and linked to local/national government agencies. The formalization of partnerships both within civil society and between civil society and state, appears crucial (Furze et al., 1996: 207; O'Riordan and Voisey, 1997; Shepherd 1998).

\footnotetext{
${ }^{2}$ It should be pointed out that NGOs are also prone to these tendencies. They are sometimes loath to surrender control of project definition and management to 'end-users', or to allow end-users to bypass them and deal directly with funders or governments (Michener, 1998).
} 


\section{The quality of participation and questions of power}

Participation by itself is often insufficient. Posing the question 'Who participates and how?' is vital to determining the type and impact of participatory EM (Uphoff, 1979; Rahnema, 1990; Nelson and Wright, 1995; Slocum, 1995). Deciding which stakeholders are included or excluded from the participatory process is critical (although techniques such as 'stakeholder analyses' exist for this purpose), especially since there can be many relevant stakeholders directly or indirectly affected by a programme. Moreover, the impact and relevance of a participatory project may be meaningless, for instance if a special effort is not made to encourage the participation of traditionally marginalized groups such as women and cultural minorities.

The kind of participation that exists is also significant (Uphoff, 1979; Pretty, 1994; Montgomery, 1988). Sometimes participation is passive or superficial, for example when governments only partially involve stakeholders in programming (i.e. after the programme's conceptual and resource allocation decisions have already been made). For participation to be meaningful, it requires involvement by relevant stakeholders in all decision-making phases and throughout the programme cycle (i.e. from design to implementation to evaluation). The Hamilton-Wentworth community initiative has raised precisely these types of issues. The initiative has had undeniable success and has received several environmental awards. Of late, however, there have been concerns about the lack of adequate citizen involvement and the impact of the Conservative provincial government's cuts to environmental programmes. An Action 2020 programme has been established to broaden community participation. But community concerns have not been allayed, some members seeing the move as merely off-loading the provincial government cuts on to the community (MacGregor, 2000: 24).

Moreover, for there to be meaningful participation, channels of information/knowledge need to be open and reciprocal, not only locally, but across borders. In programmes involving development organizations, the collection and categorization of information happens mostly in one direction (from the Western, developed countries to the rest of the world), while learning, to be true to the spirit of participation, is supposed to happen in both directions. Most often, we hear of Western technological innovations (e.g. high-yielding seeds used during the 'green revolution') being transplanted to developing countries; very seldom do we hear about 'traditional' techniques or institutions (e.g. community forestry) from the developing world being promoted by international development agencies for adoption in developed countries.

At the heart of the question of the quality of participation lies the question of power relations. The danger of using participatory approaches in EM is that, ironically, they can cut themselves off from politics (Nelson and Wright, 1995; Blackburn, 1998: 2). Communities participate in programmes without being empowered to change, dismantle or even criticize power structures. Feminists and women's groups warn, in this regard, that participation in programmes can be meaningless or even counter-productive unless women are also empowered to reform the patriarchical relations and institutions that marginalize them in the first place (Agarwal, 1997). Others point to instances where elites or private corporations have captured or manipulated participatory processes (Greider, 1992; Richards, 1995; Danguilan-Vitug, 1997). In this sense, local participatory decision-making may sometimes proceed as though all participants have an equal say, oblivious to the fact that, outside the community meeting hall or participatory workshop, elites wield socio-economic power that can influence or silence people's voices inside these spaces. Frequently, elites do not have to be present or directly represented in these spaces; the perceived threat of their power is sufficient to influence participants.

Whether due to these outside influences or not, there are several 'micro-power' processes at play within participatory spaces. Some participants may be more influential than others because they have well-supported and persuasive arguments. Others may manipulate participatory deliberations for their own ends: they may misrepresent their positions, employ false evidence or use rhetorical language to persuade, influence or silence participants (Tewdwr-Jones and Allemendinger, 1998; Holmes and Scoones, 2000). For example, a funder may organize a presentation by an 'expert scientist' at a community meeting, which may effectively discount 'local environmental knowledge'. Whether intended by the funder or not, the end result may thus be an imposed or coerced community consensus.

While much more work and experience are needed, ways of guarding against these problems could involve doing better critical contextual analysis to elucidate power inequalities inside and outside the participatory space, and making these inequalities open to questioning, dialogue and negotiation between stakeholders (Nelson and 
Wright, 1995). Participants' acknowleagment or power inequalities may induce them to devise checks and balances, for example by instituting higher than normal representation for disadvantaged socio-economic groups. In this regard, the Nepali programme has followed a 'popular education' approach, where teachers and women's groups in the programme have been empowered to engage in critical analysis of patriarchical structures (Furze et al., 1996: 98, 106ff.).

\section{Questions of community}

While community participation has pointed the way to successful and sustainable EM, there is still the danger of misrepresenting 'community'. Several examples help elucidate this problem. Sometimes, programmes may romanticize 'community', assuming that community members are 'naturally' inclined to environmentalism or equality. Yet, just because a programme is community-oriented does not imply that it will necessarily be environmentally sound: communities would need to have a record of being actively involved in conservation or else they may be inexperienced in, or unable to practice, 'traditional' conservation methods (Furze et al., 1996; Agrawal and Gibson, 1999: 633ff.).

In the same vein, feminist writers point out that, while participatory EM needs to embrace community institutions, it needs to do so with some caution. On the one hand, these writers warn that 'community institutions' may militate against, rather than encourage, women's participation (Braidotti, 1994; Goebel, 1998; Gujit and Shah, 1998; Norton, 1998). They direct our attention, for example, to the fact that several customary laws across the world discriminate against women in regards to inheritance and land rights. Such discrimination weakens women's ability to participate on an equal footing with men in local economic or agricultural decision-making. On the other hand, feminist commentators state that community participation may mean that women participate 'too much' relative to men (White, 1996), that is, when gender relations result in women bearing the brunt of 'community participation'. In HamiltonWentworth, for example, many of those involved in the unpaid, volunteer community initiatives are women. Their community work makes high demands on their already busy days, during which they must juggle professional and household work (MacGregor, 2000: 23).

A related danger is when programmes assume communities to be monolithic, thereby ignoring tnat communities tend to have multiple, and sometimes divided and conflictual, interests and actors (Nelson and Wright, 1995: 1-18; Agrawal and Gibson, 1999; Leach et al., 1999). As emphasized above, this danger is evidenced in a programme's equation of men's interests with the community's interests, and in the resulting neglect of programme impacts on women. There is also the phenomenon of 'environmental racism', for example in the U.S., where toxic waste has been dumped in locations inhabited by African-American, Latino or Native Americans (Bullard, 1993; Brook, 1998; Camacho, 1998). Here, the assumption of a single, racial/cultural community has caused EM to endanger minority communities.

As a consequence, sustainable EM would do well to acknowledge that communities are multidimensional, often containing within them differences, divisions, conflicts and inequalities. Participation can help mitigate these blind spots by emphasizing the inclusion of minorities and disadvantaged groups; yet, several of the examples noted above bear witness to these blind spots in spite of such inclusion. An important source of the blind spots appears to be the tendency for EM to place inordinate emphasis on seeking a single and once-and-for-all community consensus. Representing the community in uni-dimensional and essentialist ways makes reaching a consensus easier, but as argued above, it is often done by simplifying, imposing or coercing consensus.

One way out may be for participatory EM to refrain from seeking single and permanent decisions and solutions. Rather, an emphasis may need to be placed on encouraging debate among participants so as to enable a temporary consensus if possible, and multiple consensus when necessary (Tewdwr-Jones and Allmendinger, 1998). Resources permitting, either type of consensus will probably involve multi-pronged programming that meets the needs of plural audiences (as opposed to uni-dimensional programming that meets the needs of the majority and powerful, but leaves the disadvantaged and minorities high-and-dry). Perhaps more significantly, dynamic and multiple consensus will also allow for an agreement to disagree, and better mutual understanding among different/differing participants.

In turn, multi-consensual participatory EM will necessitate new institutional forms: coordinated, yet plural and flexible institutions to capture changing needs and diverse audiences. Some community environmental programmes have already begun to fashion these new forms (Guha, 1989; Agrawal, 1994; Furze et al., 1996). In spite of 
the qualifications noted above, the Nepali and Canadian programmes owed much of their success precisely to the existence and development of multiple institutions (panchayats, 'user groups', multiple community consultation processes) to respond to diverse community groups.

\section{Participation may not be enough}

Participation, in and of itself, may not be enough: other important factors are involved. First, for community-based EM to be effective, states need to develop property ownership regimes that entrench community rights over local resources. It is the absence of these rights that have allowed governments and private concerns to annex or appropriate communal lands/resources and, as mentioned earlier, endanger communities or community conservation (Richards, 1995; Furze et al., 1996: Ch. 9). A few workable models now exist for recognizing collective property rights (e.g. native/aboriginal 'self government' and control over natural resources in Canada).

Second, the local nature of participatory EM might be a strength in terms of decentralizing decision-making, but it is also a potential weakness in the face of economic globalization (Mohan and Stokke, 2000). In many countries, the demands of the globally-integrated economy have wreaked havoc on ecosystems at both the local and national level, with local communities too weak to do much about it (Amalric, 1999). Numerous examples can be cited here-from Brazil's increasingly deforested northeast Amazon region with local indigenous communities pitted against powerful private timber industries, to rural communities in Irian Jaya fighting against toxic waste disposal by multinational mining companies (French, 1998; Worldwatch Institute, 2000). A stronger state is not necessarily the solution to preventing such havoc. for often state collusion with the private sector is the main cause. But as suggested by Agenda 21, one way out might be to support and strengthen local, regional, national and global partnerships between communities/NGOs (supported by governments and multilateral organizations, where appropriate) (United Nations, 1992). These partnerships and networks, some of which already exist, can act as a counterbalance to transnational forces and help protect local environmental efforts (Taylor, 1995; Amalric, 1999). Of course, such an undertaking represents no small task, requiring local communities not only to attend to the intricacies of participatory EM, but where necessary, also to maintain global support networks.

\section{Conclusion}

While welcoming the shift from mainstream to participatory EM, this article has discussed some of the main challenges and dangers inherent in this shift. These include inducing resistant managers and bureaucratic cultures to change, and integrating participatory mechanisms within and between state and community actors. The task for participatory EM lies in institutionally embodying the many facets of participation and social ecology. New and plural institutional forms are being (or need to be) developed that link nature and society, tie the local to the global, facilitate information and knowledge exchange, and enable critical analysis and re-negotiation of social relationships.

Yet, in doing away with mainstream EM, in the mainstreaming of participatory EM, in the replacement of the old with the new, lies the danger of substituting one orthodoxy for another. There is the risk of bureaucratic encrustation, where plurality is unified and complexity simplified. By systematically politicizing EM, there is a tendency to favour quantity - not quality - of politics, thereby reproducing the exclusions and narrow politics of yesteryear. By making participatory spaces mirror society, there is the proclivity to re-inscribe patriarchy, racism and inequality. In being inclusive, we may, by accident or design, welcome monopoly capital and dominant western knowledge systems. By embracing and systematizing participatory EM, we run the risk of betraying it. Enthusiasm needs, then, to be tempered with constant vigilance and critique.

\section{References}

Agarwal, B. (1997). Gender, environment, and poverty interlinks: regional variations and temporal shifts in rural India. World Development 25, 1971-1991.

Agrawal, A. (1994). I don't need it but you can have it: politics on the commons. Pastoral Development Network 36, 36-55.

Agrawal, A. and Gibson, C. C. (1999). Enchantment and disenchantment: the role of community in natural resource conservation. World Development 27, $629-649$.

Alcorn, J. (1993). Indigenous people and conservation. Conservation and Biology 7, 424-446.

Amalric, F. (1998). Sustainable livelihoods: entrepreneurship, political strategies and governance. Development 41, 34-56. 
Amalric, F. (1999). Natural resources, governance and social justice. Development 43, 732-745.

Berry, J., Portney, K. C. and Thomson, K. (1993). The Rebirth of Urban Democracy. Washington, DC: Brookings Institute.

Blackburn, J. (ed.) (1998). Who Changes? Institutionalizing Participation in Development. London: Intermediate Technology Publications.

Braidotti, R. (1994). Women, the Environment and Sustainable Development. London: Zed.

Bromley, D. (1992). Making the Commons Work: Theory, Practice and Policy. San Francisco, CA: Institute for Contemporary Studies.

Brook, D. (1998). Environmental genocide: native Americans and toxic waste. American Journal of Economics and Sociology 57, 105-113.

Brush, S. and Stabinsky, D. (eds) (1996). Valuing Local Knowledge: Indigenous People and Intellectual Property Rights. Covelo, CA: Island Press.

Bullard, R. D. (1993). Confronting Environmental Racism: Voices from the Grassroots. Boston, MA: South End Press.

Camacho, D. (ed.) (1998). Environmental Injustices, Political Struggles: Race, Class and the Environment. Durham, NC: Duke University Press.

Chambers, R. (1997). Whose Reality Counts? Putting the First Last. London: Intermediate Technology Publications.

Chambers, R. (1989). The State and Rural Development. Brighton: IDS Discussion Paper No. 269.

Chambers, R. (1994a). The origins and practice of participatory rural appraisal. World Development 22, 953-969.

Chambers, R. (1994b). Participatory rural appraisal (PRA): analysis of experience. World Development 22, 1253-1268.

Chambers, R. (1994c). Participatory rural appraisal (PRA): challenges, potential and paradigm. World Development 22, 1437-1454.

Cohen, J. M. and Uphoff, N. T. (1980). Participation's place in rural development: seeking clarity through specificity. World Development 8, 213-235.

Craig, G. and Mayo, M. (eds) (1995). Community Empowerment: A Reader in Participation and Development. London: Zed.

Danguilan-Vitug, M. (1997). The politics of community forestry in the Philippines. Journal of Environment \& Development 6, 665-688.

Dyck, R. G. (1998). Integrating planning and sustainability theory for local benefit. Local Environment 3, 34-56.

Freire, P. (1970). Pedagogy of the Oppressed (M. B. Ramos, trans.). New York: Seabury Press/Continuum.

French, H. F. (1998). Investing in the Future: Harnessing Private Capital Flows for EnvironmentallySustainable Development. Worldwatch Paper No. 139. Washington, DC: Worldwatch Institute.

Furze, B., de Lacy, T and Birckhead, J. (1996). Culture, Conservation and Biodiversity. New York: John Wiley \& Sons.

Gadgil, M. and Guha, R. (1992). This Fissured Land. Berkeley, CA: University of California Press.

Garcia-Zamor, J-C. (1985). Public Participation in Development Planning and Management. Boulder, CO: Westview Press.
Goebel, A. (1998). Process, perception and power: notes from participatory research in a Zimbabwean resettlement area. Development and Change 29, 223-247.

Greider, W. (1992). Who Will Tell the People? The Betrayal of American Democracy. New York: Simon and Schuster.

Guha, R. (1989). Unquiet Woods. Berkeley, CA: University of California Press.

Guha, R. and Martinez-Alier, J. (1997). Varieties of Environmentalism. London: Earthscan.

Gujit, I. and Shah, M. K. (eds) (1998). The Myth of Community: Gender Issues in Participatory Development. London: Intermediate Technology Publications.

Holland, J. and Blackburn, J. (eds) (1998). Whose Voice? Participatory Research and Policy Change. London: Intermediate Technology Publications.

Holmes, T. and Scoones, 1. (2000). Participatory environmental policy processes: Experiences from North and South. Sussex: IDS Working Paper 113.

ICLEI (1996). The Local Agenda 21 Planning Guide. Toronto: International Council for Local Environmental Initiatives.

Leach, M. and Mearns, R. (1996). The Lie of the Land: Challenging Received Wisdom on the African Environment. Portsmouth, $\mathrm{NH}$ : Heinemann.

Leach, M., Mearns, R. and Scoones, 1. (1999). Environmental entitlements: dynamics and institutions in community-based natural resource management. World Development 27, 225-247.

MacGregor, S. (2000). Fiddling while Rome burns? sustainable communities and the politics of citizen participation. WE International Summer/Fall 21-24.

Meffe, G., Ehrlich, A. H. and Ehrenfeld, D. (1993). Human population control: the missing agenda. Conservation Biology 7, 1-3.

Michener, V. J. (1998). The participatory approach: contradiction and co-option in Burkina Faso. World Development 26, 2105-2118.

Mohan, G. and Stokke, K. (2000). Participatory development and empowerment: the dangers of localism. Third World Quarterly 21, 771-798.

Montgomery, J. D. (1988). Bureaucrats and People. Washington, DC: Johns Hopkins University Press.

Nelson, N. and Wright, S. (1995). Power and Participatory Development. London: Intermediate Technology Publications.

Norton, A. (1998). Analysing participatory research for policy change. Whose Voice? (Holland, J. and Blackburn, J., eds), pp. 179-191. London: Intermediate Technology Publications.

O'Riordan, T. and Voisey, H. (eds) (1997). Sustainable Development in Western Europe: Coming to Terms with Agenda 21. London: Frank Cass.

O'Riordan, T. and Voisey, H. (eds) (1998). The Transition to Sustainability: the Politics of Agenda 21 in Europe. London: Earthscan.

Perry, J. A. and Dixon, R. K. (1986). An interdisciplinary approach to community resource management. Journal of Developing Areas 21, 31-47.

Plein, L. C., Green, K. E. and Williams, D. G. (1998). Organic planning: A new approach to public participation in local governance. Social Science Journal $\mathbf{3 5}$, 509-523.

Pretty, J. (1994). Participatory Learning and Action. London: International Institute for Environment and Development. 
Quarles, P., Kruijt, D. and Downing, T. (eds) (1988). Hidden Crisis in Development: Development Bureaucracies. London: Free University Press.

Rahnema, M. (1991). Participatory action research: the 'last temptation of saint' development. Alternatives 15, 112-134

Raju, G. (1993). Development of People's Institutions for Management of Forests. Ahmedabad: Nehru Foundation for Development.

Redclift, M. (1984). Development and the Environmental Crisis. London: Methuen.

Redclift, M. (1987). Sustainable Development. London: Methuen.

Richards, P. (1995). Participatory Rural Appraisal: A Quick and Dirty Critique. PLA Notes, No. 24. London: IIED.

Robinson, M. (1995), Towards a new paradigm of community development. Community Development Journal 30, 21-30.

Sachs, W. (1993). Global Ecology. London: Zed.

Shepherd, A. (1998). Participatory environmental management: contradiction of process, project and bureaucracy in the Himalayan foothilis. Who Changes? Institutionalizing Participation in Development ( $\mathrm{J}$. Blackburn, ed.), pp. 88-99. London: Intermediate Technology Publications.

Shiva, V. (1986). Staying Alive: Women, Ecology and Development. London: Zed.

Shiva, V. (1991). Ecology and the Politics of Survival. New Delhi: Sage.

Slocum, R. (1995). Power, Process and Participation. London: Intermediate Technology Publications

Stanford, L. (1994). The privatization of Mexico's ejidal sector. Urban Anthropology and Studies of Cultural Systems and World Economic Development 23, 97-119.

Taylor, B. R. (ed.) (1995). Ecological Resistance Movements. New York: SUNY Press.

Tewdwr-Jones, M. and Allemendinger, P. (1998). Deconstructing communicative rationality: a critique of habermasian collaborative planning. Environment and Planning A 30, 1975-1989.

United Nations (1992). Earth Summit, Agenda 21. New York.

Uphoff, N. (1979). Feasibility and Application of Rural Development Participation: A State-of-the-Art Paper. Ithaca, NY: Rural Development Committee, Cornell University

Uphoff, N. (1992). Learning from Gal Oya: Possibilities for Participatory Development and Post-Newtonian Social Science. Ithaca, NY: Cornell University Press.

Uphoff, N. (1998). Learning about and for participation: from theoretical and empirical studies to practical experience, and back to theory. Canadian Journal of Development Studies 19, 344-366.

Viegas, P. and Menon, G. (1989). The Impact of Environmental Degradation on People. New Delhi: Indian Social Institute.

Vivian, J. M. (1991). Greening at the Grassroots: People's Participation in Sustainable Development. Geneva: UNRISD Discussion Paper No. 22.

Wapner, P. (1995). Politics beyond the state: environmental activism and world civic politics. World Politics 47, 433-454.

Weber, M. (1946). From Max Weber, Essays in Sociology (H. Gerth and C. Wright Mills, eds). New York: Oxford University Press.
Wells, M. and Brandon, K. (1992). People and Park: Linking Protected Area Management with Local Communities. Washington, DC: World Bank/WWF/USAID.

White, S. C. (1996). Depoliticising development: the uses and abuses of participation. Development in Practice 6, 6-15.

World Bank (1995). World Bank Participation Sourcebook. Washington, DC: Social Policy and Resettlement Division.

World Bank (1992). Participatory Development and the World Bank (B. Bhatnagar and A. Williams, eds). Washington, DC.

Worldwatch Institute. State of the World 2000. Washington, DC.

Zazueta, A. (1995). Policy Hits the Ground: Participation and Equity in Environmental Policy-Making. Washington, DC: World Resources Institute.

\section{Appendix}

\section{Example 1: Makalu-Barun national park and conservation area project, Nepal}

From Furze et al., 1999: 12-13, 106-108

This project was established in 1988 and is jointly-run by the Woodlands Mountain Institute (an environmental NGO) and the Government of Nepal. The goal of the project is to protect regional biodiversity by integrating national park management with participatory conservation area management. The project gives local communities a direct stake in biodiversity protection, and integrates this activity with a broader community development approach that includes: the development of poverty mitigation projects, the provision of skills and training to local people (in sustainable agricultural techniques, wildlife and park management, eco-tourism and eco-trekking, marketing, small retail, development of linkages with outside markets for local products, etc.), and the creation of socially-relevant institutions and programmes (improvement of schools and drinking water facilities, development of women's microcredit institutions, etc.). Local communities and institutions are involved in all aspects of project design, development and implementation, with interactive planning meetings (organized by the local panchayats or village governments) taking place regularly throughout the region to encourage community dialogue. What is also noteworthy is the deployment of 'user groups' that maximize participation in resource management and socio-economic development by allowing all those involved and affected by various programmes to provide input and feedback on an on-going basis. 
Example 2: The sustainable community initiative in the regional municipality of Hamilton-Wentworth, Canada

From ICLEI, 1996: 182ff

Located just west of Toronto, Hamilton-Wentworth is a large, urban, multicultural agglomeration encompassing about 6 million people and 6 defferment municipalities. The area is home to a large steel industry, and over the years has witnessed a number of toxic accidents, high air/water pollotion, and the problem of toxic waste dumps. A municipal Regional Council is responsible for providing water and sewerage, major roads, public transit, police, social services, public health services, economic development and regional land use planning. Beginning in 1989, the Regional Council and local citizens initiated a sustainable devilopment mechanism to improve municipal decisionmaking and incorporate community concerns about the need to balance social, economic and environmental issues. Through an extensive consultation process lasting two and a half years, a Citizen's
Task Force helped develop an overall vision ('Vision $2020^{\prime}$ ) to guide future development, establish pubic outreach programmes to increase awareness of sustainable development issues, and provide direction to the Regional Council on economic development strategies. The community consultaion process (bringing together local government, citizens, NGOs, and the private sector) highlighted 11 key priorities, including protection of natural areas and corridors, improvement of water and air quality, waste reduction, energy reduction, better land use and modes of public transportatimon, improved personal health and well-being, development of the local economy, and community empowerment/participation in local government. Vision 2020 also came up with concrete performmance targets in all priority areas, linking them to municipal decision-making and resource altocation. Every year, the Task Force publishes an Annual Report Card and organizes a 'Sustainable Community Day', where the municipality, citizens and other local stakeholders and intitutions come together to assess progress towards Vision 2020. 